\title{
International collaborative military mapping programs' implementation and development opportunities in Hungary
}

\author{
NYERGES János ${ }^{1}$, KULCSÁR Gábor ${ }^{2}$
}

\begin{abstract}
The two most important military mapping projects in Hungary are the Multina- tional Geospatial Coproduction Program (MGCP) and the SAAB JAS 39 Gripen aircraft support, with digital mapping system. 29 countries joined the largest mapping program, called the MGCP to create up-to-date, 50k scale, high density $1^{\circ} \times 1^{\circ}$ cells for a geospatial database to cover the majority of the global landmass. Hungary has been a participant since December

2005, and contracted $28+1$ data cells for completion by 2013.

Under the terms of the Gripen lease-purchase agreement, Hungary has to provide basic data for the aircraft on-board system which requires continuous database maintenance for both surface and obstacle databases. Another task is to maintain the Digital Map Generating System (DMGS).

Keywords: Multinational Geospatial Co-production Program (MGCP), SAAB JAS

39 Gripen (Gripen), Digital Map Generating System (DMGS);
\end{abstract}

Since 2001, the Ministry of Defense (MoD) Zrínyi Mapping and Communication Servicing Non-profit Limited Company (MoD Mapping Company) perform the geoinformatics tasks (supply and produce) of the MoD. The tasks are monitored and controlled by the Geoinfor- mation Service (GEOS) of the Hungarian Defense Forces (HDF).

Tasks for a year are mainly the responsibility of the GEOS HDF. State-finance is a crucial aspect, which fundamentally determines the amount of tasks that can be performed.

The company has 2 main mapping projects:

1. Multinational Geospatial Co-production Program (MGCP)

2. SAAB JAS 39 Gripen aircraft support with Digital Map Generating System (DMGS)

\section{Multinational Geospatial Co-production Program}

\section{History}

Hungary and Hungarian cartography (together with other nations) have the possibility of par- ticipating in the world's largest mapping project, and of contributing to practical applications. The geospatial database is based on international standards.

The basic concept of the MGCP program was built in the late 80's, when the U. S. De- fense Mapping Service, now known as U.S. National Geospatial Intelligence Agency (NGA), proposed to create a high-resolution digital database covering all of the continents.

1 digital cartography department, Ministry of Defense Mapping Non-Profit Company kulcsar.mail@gmail.com

2 financial and accounting department, Ministry of Defense Mapping Non-Profit Company

NYERGES János, KULCSÁR Gábor: International collaborative military mapping programs’ implementation...

In April 2003, in Vancouver, at the conference of national mapping services, the NGA initiated the launch of the Multinational Geospatial Co-production Program (MGCP)

There are 29 nations participating in the program. The program is managed by the NGA, cooperating with the Leading Nations (nations contracted for more than 200 cells). They are responsible for the implementation and coordination of regional cooperation and assistance to participating nations. The leading nations are: Australia, Canada, Denmark, France, Ger- many, Italy, Norway, Spain, Sweden, United Kingdom, and the USA.

The geospatial database consists of $1^{\circ} \times 1^{\circ}$ degree cells. The cells must be produced from remote sensing source data (not older then 3 years); all costs must be covered by the produc- ing nation.

\section{The aim of the program}

The program aims to create a modern, up-to-date digital geospatial database which can cope with 21 st century challenges. The program will set up global 1:50 000 and 1:100 000 scales (equal data density with the topographic maps) geospatial databases with modern data con- tent in $1^{\circ} \mathrm{x} 1^{\circ}$ degree cells.

As a result, every participating country has the rights to access a geospatial warehouse, called the International Geospatial Warehouse (IGW), where all the nations' cells are stored. All the cells are homogeneous in data and based on 


\section{Implementation Process}

For the $1^{\text {st }}$ phase there was a 1+5 year time frame (between 2006 and 2011) for data produc- ing (the first year for the test cell, and five more years for the additional cells), but based on the nation's common decision they extended this timeframe by two more years. By the end of the decade, the first military needs database will be ready.

The criteria for access data in IGW is to have (at least) five finished, Quality Controlled (QC) and uploaded $1^{\circ} \times 1^{\circ}$ cells.

\section{Hungary's participation}

Hungary joined the program in December, 2005 by undertaking $28+1$ cells.

The following procedure is used for preparation and uploading:

- GEOS HDF is responsible for realization of the program;

- MoD Mapping Company, Digital Cartography Dept. is responsible for the technical implementation.

After finishing and uploading the 28+1 cells, Hungary has the rights to download 113

cells from IGW. This would be enough to download e.g. all Afghanistan's cells.

In 2012 the chairman of MGCP TG called upon Hungary to be the custodian of one of the technical documents. This document is part of the QC process.

NYERGES János, KULCSÁR Gábor: International collaborative military mapping programs’ implementation...

\section{The status of implementation}

The professional resources are available at the MoD Mapping Company.

Since January 2013 Hungary has finished $23+1$ cells of the $28+1$.

\begin{tabular}{|l|c|c|c|c|c|c|c|}
\hline Location & $\begin{array}{c}\text { Contract- } \\
\text { ed }\end{array}$ & Accepted & $\begin{array}{c}\text { Waiting } \\
\text { for ac- } \\
\text { ceptation }\end{array}$ & $\begin{array}{c}\text { In pro- } \\
\text { duction }\end{array}$ & $\begin{array}{c}\text { Waiting } \\
\text { for data } \\
\text { capture }\end{array}$ & $\begin{array}{c}\text { Reserved } \\
\text { for Phase } \\
2\end{array}$ & $\begin{array}{c}\text { Planned } \\
\text { for Phase } \\
2\end{array}$ \\
\hline Test cell & 1 & 1 & & & & & \\
\hline Europe & 9 & 9 & & & & & \\
\hline Africa & 19 & 13 & 1 & 1 & 4 & 5 & 18 \\
\hline Total & $\mathbf{2 9}$ & $\mathbf{2 3}$ & $\mathbf{1}$ & $\mathbf{1}$ & $\mathbf{4}$ & $\mathbf{5}$ & $\mathbf{1 8}$ \\
\hline
\end{tabular}

Chart 1. MGCP status in Hungary 2013

Unfortunately, in autumn 2008 the economic crisis was still reflected in the financing of mapping tasks. In 2009 the lack of raised funds caused the failure of the original plan (one cell was not finished). In 2010 the program was entirely removed from the budget of MoD. After that, the programs were restarted in Hungary.

In this financial crisis the MoD Mapping Company tried to minimize the costs of the Program. By reorganizing the internal resources they put the QC in-house at the last two African cells.

In 2011 MoD Mapping Company started an In-house production. After substantial prepa- ration 6 operators have been trained. Now only two, but experienced, operators are working on data capture.

Based on the last 2 years, the funding of the programs is balanced now. The Ministry sees the project's crucial role, so every year warrants the necessary financing.

Since only two companies are involved in the program (GEOS HDF and MoD Mapping Company) the workflow has sped up. The two operators are able to finish four cells per year, and the active participation on the technical meetings results in a smooth international accep- tance process and high data quality.

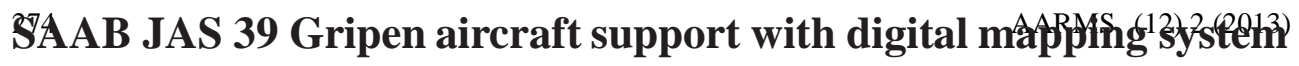

Under the terms of the Gripen lease-purchase agreement, Hungary has to provide basic data for the aircraft on-board system which requires continuous database maintenance for both surface and obstacle databases. Another task is to maintain the Digital Map Generating Sys- tem (DMGS).

NYERGES János, KULCSÁR Gábor: International collaborative military mapping programs’ implementation... 


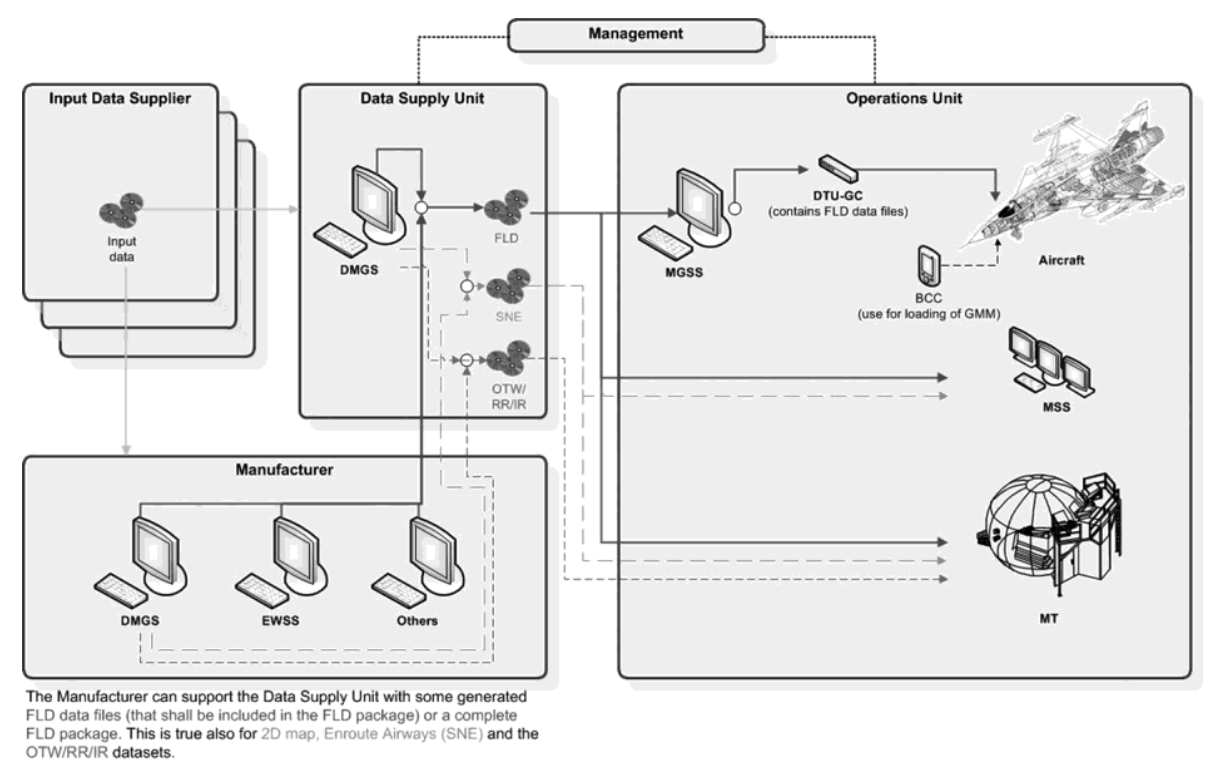

Figure 1. A functional overview of the geographical and aeronautical data supply process for the Gripen materiel system, including organizations, tools, materiel system components and data deliveries

(yellow lines $=$ input data files, blue lines $=$ FLD files or FLD package, green lines $=$ SNE datasets

(e.g. 2D map and Enroute Airways),

red lines $=O T W / R R / I R$ datasets $)^{3}$

\section{Beginnings}

In 2001 the Swedish and Hungarian governments entered into a lease-purchase agreement, with a further modification in 2003 that included 14 Gripen C/D (12 single-seater and 2 two-seater aircraft). All aircraft were delivered in 2006 and 2007, and all 14 aircraft were in operation with the Hungarian Air Force by the end of 2008.

As the first step of the Hungarian Defence Forces Network-based warfare capability, at the time of Gripen aircraft acquisition, the relationship elements between the aircraft and the air command \& control system had to be established. It has to develop the mapping and GIS systems as well as the similar elements for the air command \& control system. The Swedish partner provided the necessary courses for the GIS professionals. The first courses were held in Sweden between 2004 and 2005.

During 2005 and 2006, the first ten Hungarian pilots also concluded their training. To date a total of 22 pilots have completed their training. The training of technicians and ground crews was completed in March 2007.

NYERGES János, KULCSÁR Gábor: International collaborative military mapping programs’ implementation...

\section{Applied databases}

As the starting databases DTA50 (1:50.000 data density), DTA 200 (1:200 000) DTA 1000 (1:1 000 000) digital topographic databases were provided. Besides the topographical data- bases ortho imagery (over special areas of interest), Landsat satellite images (over the whole country) have been used as background information.

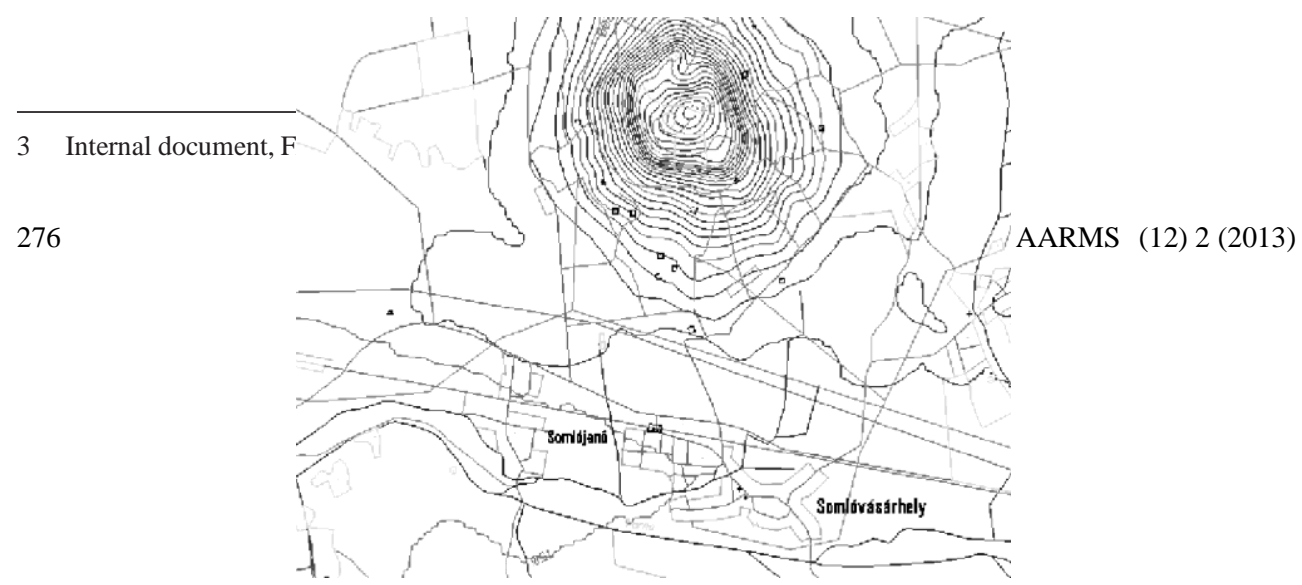

Figure 2. DTA $50^{4}$ 
The Digital Obstruction Database from a $60 \mathrm{~m}$ height (which based on geodetic survey) has been used and was last updated in 2008, and as a special safety requirement, a $25 \mathrm{~m}$ ob- stacle database has been surveyed for the airfields.

\section{Digital Map Generating System}

The Digital Map Generating System (DMGS) provides the aircraft, as well as the support systems and training simulators, with correlated geographical data. The DMGS imports var- ious geographical source data formats into a single common database, from which data is selected and refined to enable export of the desired output format. (Saab $\mathrm{AB}, 2013)$

The first DMGS system (version 2.3) was installed in 2006. Then 2.6.1's followed, then

3.2, and then the still used 3.4 version, which runs on a Windows server environment.

The databases are updated annually, with the exception of the airspace structure database, which immediately follows the changes.

The Software Development Plan (SDP) defines development and management of the Field Loadable Data (FLD) for the Gripen materiel system. The SDP is provided by the Swedish Defence Materiel Administration and it is intended for use in the Hungarian Air Force. At this time there is no responsible organisation for it, the FLD is produced and verified according to the instructions in the SDP. Without a verified process, the FLD cannot be used.

NYERGES János, KULCSÁR Gábor: International collaborative military mapping programs’ implementation...

\section{Future of the Gripen aircraft support with digital mapping system}

Hende Csaba, Minister of Defence, announced on 2012 November 13th that Hungarian Grip- ens will perform air policing over Slovenia and the Baltic States under the terms of a NATO agreement.

The Minister said that Hungary's Gripens are to guard Slovenia's airspace soon, while they are expected to participate in Baltic Air Policing between 2015 and 2018.

Slovenia, like Estonia, Lithuania and Latvia, does not have its own air policing capabilities, so other NATO-member states take turns in providing air policing. This is the first time that Hungary and its Gripens will protect and monitor the skies over Slovenia and the Baltic States.

The current contract with the Swedish government was due to expire in 2016, but the countries have now decided to extend the partnership by another ten years.

The most important task for the Gripen support would be to define the responsibility lev- els between the concerned organizations.

\section{Summary of a possible future of the Multinational Geospatial Co-production Program}

In order to achieve common goals, the MGCP program is an excellent example of coopera- tion between nations with the consolidation of resources which results in an outcome for all participants with multiple returns.

Hungary and Hungarian cartography (with other nations) have the possibility to partici- pate in the world's largest mapping project, and contribute to practical applications.

The first phase will be finished by the end of 2013. From 2014 we will be able to start the second phase. The aim is to upload 51 cells and to be able to access more than 300 cells from the warehouse.

The most important benefit is the program's aim itself: the ability to give geospatial sup- port to the military missions with the most up-to-date databases. In case of any foreign mis- sions for soldiers e.g.: in Mali or Afghanistan, they will be able to download geospatial data- base or even up-to-date paper maps over the area. This is why the Program was established. On the other hand the Hungarian military's Geographic Information System (GIS) experts acquire

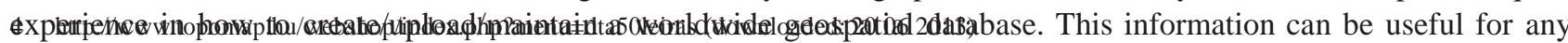
national database. The participants establish international relationships in leadership and technical experience as well.

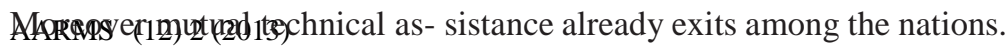

277

MGCP software technology can be used in other projects. For example the special data checking software, called Geospatial Analysis Integrity Tool (GAIT), is a free software (for military purposes) and has a wide variety of checks which are able to shorten the Quality Control process time.

\section{Conclusion}

As soon as the SDP is well defined, they will be able to produce verified databases not only for the Hungarian Air Force but for the Thai and Czech Air Force as well, since they have not got the DMGS. 
In our opinion, it would be worthwhile to expand the MGCP work in-house, increasing the number of operators, and thus be able to produce at least 12 cells in a year. The more cells produced means the more the contributer can access from the international warehouse. The first planned $28+1$ cells are easily obtainable, and for 51 cells it only needs to continue for a few more years. The knowledge is there, just waiting for the necessary decision.

\section{Appendix A: Definitions, Terms and Acronyms}

\begin{tabular}{ll} 
BAR & Bar Code Computer. \\
DMGS & Digital Map Generating System \\
DTA & Digital Topographic Database \\
DTU-GC & Used for transferring FLD files to the aircraft. ESRI \\
\multicolumn{2}{l}{ Environmental Systems Research Institute EWSS Electronic Warfare } \\
Support System \\
FLD & Field Loadable Data \\
GAIT & Geospatial Analysis and Integrity Tool \\
GEOS HDF & Geoinformation Service of the Hungarian Defense Forces \\
GIS & Geographical Information System \\
GMM & Gripen Moving Map \\
HDF & Hungarian Defense Forces \\
IGW & International Geospatial Warehouse \\
IR & Infrared Image \\
MGCP & Multinational Geospatial Co-production Program \\
MGCP TG & Multinational Geospatial Co-production Program Technical Group \\
MGSS & Maintenance Ground Support System \\
MOD & Ministry of Defense MSS \\
System MT & Mission Trainer \\
NATO & North Atlantic Treaty Organization \\
NGA & National Geospatial Intelligence Agency \\
OTW & Out the Window database, simulation environment in the mission trainer system \\
RR & Radar image dataset \\
SDP & Software Development Plan \\
SNE & Synthetic Natural Environment dataset \\
QC & Quality Control
\end{tabular}

\section{References}

CSERI, J., MOLNÁR O. (2009): Globális kihívások a katonai térképészet területén, In. Geodézia és Kartográfia 3. szám, pp. 1518.

BRUNBAUER, O. (2006): Többnemzeti Térinformatikai Együttmüködési Program: Tesztcella elöállítása, Budapest:

Geodézia Zrt. Térinformatikai Osztály www.geodezia.hu/letoltes/Brunbauer_Otto_MGCP.ppt (downloaded: 2006 2013)

NYERGES János, KULCSÁR Gábor: International collaborative military mapping programs’ implementation...

FARKAS, I. (2009): Multinational Geospatial Co-production Program — Production worldwide and in Hungary, In. AARMS Vol. 8 No. 1, pp. 151-157.

SZABÓ, Gy. (2005): Többnemzeti Térinformatikai Együttmüködési Program szerepe és feladatai egy egységes térinformációs világrendszer létrehozásában, Országos Térinformatikai Konferencia, Szolnok http://www.otk.hu/cd05/3szek/Szab\%C3\%B3\%20Gyula.htm (downloaded: 2006 2013)

SAAB AB (2013): Digital Map Generating System; Geographical data Supply http://www.saabgroup.com/en/Air/Mission_Support_Systems/Correlated_Geographical_Data/

AARMS (12)Bigital_Map_Generating_System/(downloaded: 2006 2013) 